\title{
ORIGENS, EVOLUÇÃO E TENDÊNCIAS DO SETOR HOTELEIRO DE BALNEÁRIO CAMBORIÚ/SC ${ }^{1}$
}

ORIGINS, EVOLUTION AND TRENDS OF THE HOTEL INDUSTRY IN BALNEÁRIO CAMBORIÚ/SC

\section{ORÍGENES, EVOLUCIÓN Y TENDENCIAS DEL SECTOR HOTELERO DE BALNEÁRIO CAMBORIÚ/SC}

\section{Raquel Maria Fontes do Amaral Pereira}

Universidade do Vale do Itajaí - UNIVALI

Doutora em Geografia Humana pela Universidade de São Paulo raquelfontespereira@gmail.com Data de Submissão: 12/03/2015

Data de Aprovação: 09/06/2015

Resumo: O presente artigo analisa as origens, a evolução e as tendências da rede hoteleira do Balneário Camboriú, associadas à expansão urbana e turística na faixa litorânea catarinense. A área objeto de estudo compreende o espaço urbano de Balneário Camboriú/SC, um dos maiores destinos turísticos do Sul do Brasil, cuja organização espacial definida ao longo de diferentes períodos tem passado por um acelerado processo de transformação imposto, inicialmente, pela ampliação do número de veranistas, seguido pelo crescimento dos fluxos turísticos. O método de abordagem apoia-se no materialismo histórico-dialético, recorrendo fundamentalmente ao paradigma de formação socioespacial que favorece a identificação das "múltiplas determinações" responsáveis pela caracterização de realidades concretas, bem como na consideração do papel da pequena produção mercantil para explicar a dinâmica socioeconômica das áreas coloniais do Sul do Brasil. O texto discute as iniciativas pioneiras e as principais características da rede de hotéis relacionadas às diferentes etapas de expansão da cidade, bem como a sua relação com o contexto estadual e nacional, levantando as permanências e as transformações do setor, assim como as determinações locais, regionais, nacionais e mundiais, responsáveis por sua dinâmica atual.

Palavras-chaves: Balneário Camboriú. Setor Hoteleiro. Origens, evolução e tendências.

Abstract: This article analyzes the origins, evolution and trends of the hotel network of Balneário Camboriú, associated with the urban and touristic expansion on the coast of the state of Santa Catarina. The area that is the subject of study comprises the urban space of Balneário Camboriú/SC,

1 O presente artigo tem sua origem no projeto de Iniciação Científica (PIBIC/CNPq) desenvolvido pela acadêmica Naiara Fernanda Guth do Curso de Arquitetura e Urbanismo da UNIVALI, sob minha orientação. 
one of the main tourism destinations in the South of Brazil, in which the spatial organization, defined throughout different periods, has been undergoing an accelerated process of transformation, initially imposed by the increase in the number of summer vacationers, followed by the growth of tourism flows. The approach method is supported by dialectical and historical materialism, essentially resorting to the socio-spatial paradigm, which favors the identification of the "multiple determinations" responsible for the characterization of concrete realities, as well as in the consideration of the role of small-scale mercantile production to explain the socioeconomic dynamics of the colonial areas of Southern Brazil. The text discusses the pioneering initiatives and the main characteristics of the hotel network in relation to the different stages of the city's expansion, as well as its relation with the state and nationwide contexts, investigating permanencies and transformations of the sector, and the local, regional, national and international decisions responsible for its current dynamics.

Keywords: Balneário Camboriú. Hotel Industry. Origins, evolution and trends.

Resumen: El presente artículo analiza los orígenes, la evolución y las tendencias de la red hotelera de Balneário Camboriú asociadas a la expansión urbana y turística en la zona costera catarinense. El área objeto de este estudio comprende el espacio urbano de Balneário Camboriú/SC, uno de los mayores destinos turísticos del sur de Brasil, cuya organización espacial, definida a lo largo de diferentes períodos, ha pasado por un acelerado proceso de transformación impuesto, inicialmente, por la ampliación del número de veraneantes y seguido por el crecimiento de los flujos turísticos. El método de abordaje se apoya en el materialismo histórico dialéctico, recurriendo fundamentalmente al paradigma de formación socio espacial que favorece la identificación de las "múltiples determinaciones" responsables por la caracterización de realidades concretas, así como en la consideración del papel de la pequeña producción mercantil para explicar la dinámica socioeconómica de las áreas coloniales del sur de Brasil. El texto discute las iniciativas pioneras y las principales características de la red de hoteles relacionadas a las diferentes etapas de expansión de la ciudad, así como su relación con el contexto provincial y nacional, estudiando las permanencias y las transformaciones del sector, así como las determinaciones locales, regionales, nacionales y mundiales, responsables por su dinámica actual.

Palabras clave: Balneário Camboriú. Sector Hotelero. Orígenes, evolución y tendencias.

\section{INTRODUÇÃO}

\section{7 área objeto do presente estudo corresponde ao município de Balneário Camboriú/SC, que possui $46,6 \mathrm{~km}^{2}$. Criado em 1964, foi 1 desmembrado do vizinho município de Camboriú e situa-se na} denominada região da Associação dos Municípios da Região da Foz do Rio Itajaí-Açu (AMFRI). Conforme estimativa registrada pelo Instituto Brasileiro de Geografia e Estatística (IBGE), datada de julho de 2013, Balneário Camboriú possui 120.926 habitantes fixos, tendo recebido 628.803 visitantes na alta temporada de 2013 (janeiro/ fevereiro), de acordo com a pesquisa de demanda realizada pela Santa Catarina Turismo AS (SANTUR). 
O turismo constitui uma importante atividade no contexto econômico do estado de Santa Catarina, em razão da singularidade de sua formação socioespacial que deu origem a um mosaico de paisagens propiciadoras do desenvolvimento desse setor, colocando-o numa posição de destaque no cenário nacional. A atividade turística foi impulsionada pelo advento das revoluções tecnológicas, visto que o seu desenvolvimento está diretamente ligado à melhoria dos meios de locomoção, à expansão urbana e ao crescimento da economia capitalista que após o término da II Guerra Mundial entrou em um novo período de expansão, no qual o Brasil se inseriu com grande dinamismo.

Se até muito recentemente a prática do turismo se apresentava como um privilégio de uma elite bastante reduzida, nas últimas décadas tornou-se acessível a diferentes camadas sociais, em razão da melhoria dos meios de comunicação e de transportes que contribuíram para a redução das distâncias e dos custos, facilitando o deslocamento de pessoas. Também a ampliação do tempo livre, regulamentado por leis, após longa luta das classes operárias, favoreceu igualmente o crescimento do turismo em escala global, tornando essa prática acessível a um crescente número de pessoas. Foi, pois, somente a partir de meados do século passado que o turismo se consolidou como uma atividade de massa, estimulada pela melhoria dos meios de transporte, em especial pelo incremento maciço da aviação comercial (MONTEJANO, 2001) e pela ampliação da rede rodoviária.

No caso de Santa Catarina, a organização socioespacial dos municípios situados na faixa litorânea vem passando por grandes transformações decorrentes da demanda provocada pelo aumento da população residente e dos fluxos turísticos estimuladores da implantação progressiva de uma estrutura de serviços urbanos. Esse novo processo de produção e de apropriação do espaço, por sua vez, resulta de mudanças ditadas pela lógica capitalista que, além de alterarem as características da paisagem natural, reduziram também as marcas de sua história, o que leva ao entendimento de que para analisar as transformações ocorridas na formação litorânea catarinense faz-se necessário buscar elementos explicativos em diferentes escalas geográficas (local, regional, nacional e internacional). Para tanto, é preciso considerar o contexto socioeconômico nacional e mundial e seus reflexos sobre o setor hoteleiro, 
ISSN: 1983-7151

buscando compreender a sua evolução no plano regional. Os espaços não podem ser estudados como se os objetos contidos na paisagem guardassem em si mesmos sua própria explicação, o que exige a consideração dos processos geradores das formas. Isso significa reconhecer como fundamentais as noções de tempo e espaço, já que a produção espacial resulta de múltiplas determinações, cujas origens se situam em níveis diferentes e em escalas variáveis, indo do simples lugar à dimensão internacional (SANTOS, 1986, p.41).

As redes internacionais de hotéis começaram a entrar no Brasil apenas em meados da década de 1970, com o crescimento da economia e a implantação de empresas multinacionais decorrente do acirramento da concorrência entre elas e pela transformação do país em importante polo de viagens de negócios. A instalação de unidades integrantes das grandes cadeias hoteleiras coincide com uma fase de disponibilidade de financiamento de longo prazo e de incentivos fiscais para construção de hotéis. No caso de Santa Catarina, porém, a entrada das redes hoteleiras ocorreu em meados da década de 1990, tardiamente, se comparada a outras capitais do Brasil. Em 1995, conforme Santos (2012), o estado recebeu dois empreendimentos pertencentes ao grupo francês Accor, inaugurados nas cidades de Florianópolis (Hotel Parthenon Lindacap) e São Bento do Sul (Hotel Novotel São Bento do Sul).

Assim, pode-se afirmar que a forma, no caso da rede hoteleira de Balneário Camboriú, está vinculada inicialmente a estruturas simples, a técnicas simples que vão se alterando continuamente ao longo do tempo para acompanhar as transformações da sociedade. Os lugares e os objetos neles contidos são carregados de uma parcela do dinamismo social, razão pela qual, a cada fase histórica, a função de cada estrutura social, assim como o seu conteúdo, se altera. Isso quer dizer que, na organização do espaço atual, convivem formas herdadas de diferentes épocas, às quais cada movimento da sociedade atribui um novo papel. Para interpretar a rede de hotéis de Balneário Camboriú não basta, pois, analisar apenas os elementos que a compõem atualmente, mas reconhecer que ela é fruto de determinações do passado e do presente e que recentemente, apesar do acelerado processo de expansão urbana e do aumento dos fluxos turísticos, foram registradas poucas mudanças na hotelaria local e estadual, representada em sua maioria por empreendimentos de caráter familiar. 
Por meio de reflexões teóricas propiciadas pelas categorias analíticas utilizadas e da coleta de dados em fontes bibliográficas específicas, bem como junto às instituições ligadas ao setor hoteleiro, antigos moradores e empreendedores, são analisadas ao longo do artigo as origens, a evolução e as tendências da rede hoteleira do Balneário Camboriú, associadas à expansão urbana e turística na faixa litorânea catarinense. As transformações socioespaciais ocorridas em Balneário Camboriú, sobretudo na área correspondente à Praia Central, foram provocadas pelo avanço da urbanização em consequência do desenvolvimento das atividades de veraneio e turísticas, as quais acabaram atraindo investimentos, entre outros, para o setor hoteleiro. Segundo dados colhidos juntos a Secretaria de Turismo do Município de Balneário Camboriú (SECTUR-BC), a cidade possui atualmente a maior rede hoteleira do Sul do Brasil, totalizando 15.074 leitos distribuídos entre 92 hotéis e pousadas², espalhados pelos seus diferentes bairros. Uma das características destes meios de hospedagem é a propriedade de administração familiar, visto que poucos pertencem a redes, sendo pouquíssimos os hotéis de bandeiras internacionais instalados no Balneário Camboriú. Tal fato está relacionado a uma série de fatores, entre os quais pode se destacar a vitalidade da pequena produção mercantil catarinense, que permitiu a acumulação do capital investido nestes empreendimentos e o padrão de gastos dos turistas, bem como um provável esforço dos próprios empreendedores no sentido de manter uma reserva de mercado.

A pesquisa foi desenvolvida com base no método histórico-dialético, recorrendo fundamentalmente ao paradigma de formação socioespacial (SANTOS, 1982), que favorece a identificação das "múltiplas determinações" responsáveis pela caracterização de realidades concretas. A linha interpretativa apoiou-se também na perspectiva teórica desenvolvida por Mamigonian (19661986), que destaca o papel da pequena produção mercantil para explicar a dinâmica socioeconômica das áreas coloniais do Sul do Brasil. Os resultados da investigação realizada permitiram comprovar a validade do referencial teórico utilizado para decifrar as origens, a evolução e as tendências do setor hoteleiro do município de Balneário Camboriú/SC.

2 Dados disponibilizados pela Prefeitura Municipal de Balneário Camboriú. Há, entretanto, uma divergência entre o número de meios de hospedagem do município disponibilizados pelo Sindicato de Hotéis, Restaurantes, Bares e Similares (SINDISOL), pela Secretaria de Turismo (SECTURBC) e pela Prefeitura Municipal. 


\section{BREVE HISTÓRIA DA HOTELARIA: MUNDO, BRASIL E}

SANTA CATARINA

A palavra hotel tem origem nos vocábulos latinos hospes, que significa pessoa alijada ou hóspede; e hospitium, designação dada ao lugar onde se abrigavam, na antiguidade, além de enfermos, viajantes e peregrinos. Para Castelli (2005), existem outras palavras que representam momentos de sociabilidade, acolhimento e hospitalidade, tais como hospitalia (albergue público), hospitalis (hóspede), stabulum (albergue com estábulo), mansiones (casas de hospedagem), usadas como paradouro de tropas militares em trânsito, correio e, posteriormente, de todos os visitantes. Já a denominação de "hotel" é recente, deriva do francês antigo "hostel", depois "hotel", significando, no século XVII, "pousada" (CAMPOS, 2005).

Cabe destacar, com base em Pires (2001, p. 20) que "o protótipo do hotel moderno surgiu, ao que parece antes mesmo da grande revolução nos transportes e seu desenvolvimento prende-se, num primeiro momento, não à estrada de ferro ou ao vapor, mas a um antigo meio de transporte: a diligência". Até o surgimento das ferrovias, por volta de 1840, os meios de hospedagem foram se multiplicando no que diz respeito à quantidade, mas não à qualidade e tampouco à modernização. Algumas das maiores pousadas dessa época foram instaladas especificamente para se integrar com o meio de transporte dominante até então, representado pelas carruagens. Sua importância era grande de tal modo que os meios de hospedagem mais bem equipados possuíam cocheiras e estábulos que acomodavam os cavalos que puxavam essas carruagens.

A primeira Revolução Industrial ocorreu na Inglaterra no final do século XVIII, tendo como principais invenções a máquina a vapor e a máquina de fiar, promovendo a grande expansão do Império Britânico. A Inglaterra tornou-se a primeira grande potência capitalista, dando início a uma fase de expansão da economia mundial, que se estendeu de 1790 a 1821. Esse período de expansão econômica foi sucedido por uma fase recessiva do ciclo longo ou ciclo de Kondratieff ao término da qual a máquina a vapor foi aplicada 
aos meios de transporte (trens e navios), fato que resultou numa grande revolução nos transportes que, por sua vez, levou à modernização dos meios de hospedagem. Nas primeiras décadas do século XIX surgiram as primeiras ferrovias na Europa. Em consequência, os meios de hospedagem tiveram que se adaptar aos novos meios de transporte, o que levou à construção de hotéis e pousadas nas proximidades das estações ferroviárias e não mais apenas ao longo das vias percorridas pelas diligências e/ou carruagens. Ainda conforme Pires, "nessa época, os Estados Unidos começaram a avançar mais depressa que a Europa, passando de 65 quilômetros de ferrovias em 1830 para 4.509 quilômetros, chegando a 14.000 quilômetros em meados do século". Já no ano de "1860 a Europa e os Estados Unidos partilhavam, quase igualmente, 108.000 quilômetros, enquanto as outras partes do mundo contavam com apenas 15.000 quilômetros" (2001, p. 9-10).

Paralelamente à expansão da rede ferroviária, houve também melhorias significativas nas estradas de rodagem, uma delas representada pela invenção do macadame, na segunda metade do século XVIII, por John Loudon Mc Adam, o qual consistia em um processo de consolidação do piso das estradas, substituindo as camadas de pedra pela utilização de cascalho com um leve arqueamento do piso, o que barateou a construção de rodovias.

Assim, diante do susto industrial, os meios de transporte que haviam ficado atrasados passaram por grandes transformações com a aplicação da máquina a vapor, não apenas as locomotivas, como também a navegação no período depressivo do primeiro ciclo longo (1815 - 1848), provocando uma verdadeira explosão de crescimento entre 1848 - 1873 (fase expansiva do segundo ciclo longo). A navegação de cabotagem no Brasil até meados do século XX teve um grande significado, transportando mercadorias e pessoas, e movimentando as praças comerciais de cidades portuárias ao longo de todo litoral (MAMIGONIAN, 2013). Com a definição de políticas públicas que privilegiaram a implantação do sistema rodoviário federal, a navegação de cabotagem entrou em decadência.

Em decorrência da ampliação do sistema rodoviário nacional e estadual, a navegação de cabotagem, largamente praticada no litoral, entrou em decadência, visto que, paralelamente à lenta integração da economia local e à 
economia capitalista de mercado, acontecia a desestruturação da economia de autossuficiência. Essa nova realidade trouxe mudanças significativas para todas as regiões brasileiras e, em particular, para a capital e os demais núcleos urbanos do litoral catarinense, resultantes da ampliação do sistema rodoviário, bem como da nova conjuntura socioeconômica do país ${ }^{3}$. Apesar de essas localidades terem permanecido vinculadas à estrutura econômica anterior à Revolução de 1930, foram partir das décadas de 1950 e 1960, rompendo gradativamente o longo período de estagnação.

Na década de 1960, o litoral catarinense começou a receber veranistas provenientes do Rio Grande do Sul, Paraná e interior do próprio estado de Santa Catarina. Conforme registro de C. A. Figueiredo Monteiro (1963), nessa década eles já ocupavam os principais balneários do Estado. Enquanto as praias de Cabeçudas, Camboriú (atual Balneário Camboriú) e Porto Belo recebiam prioritariamente veranistas da região de Blumenau; ao litoral do extremo norte, onde se localizam as praias de Ubatuba, São Francisco do Sul, Itajuba e Barra Velha, afluíam moradores de Curitiba, Joinville e áreas circunvizinhas. O fluxo de gaúchos procedentes, sobretudo, da região de Porto Alegre, era registrado nas praias do sul catarinense.

Com a construção de vias de ligação entre os grandes centros e as cidades portuárias, o número de hotéis aumentou significativamente, propiciando o crescimento do número de viajantes, o que acabou por promover o desenvolvimento do turismo. No Brasil, mais do que em qualquer outra cidade portuária da época, o Rio de Janeiro foi beneficiado pelo novo status de sede do reino ao abrigar a partir de 1808 a Família Real, passando por grandes transformações em relativamente curto espaço de tempo (PIRES, 2001, p. 3233). "O episódio da transferência da família real portuguesa para o Brasil e a consequente abertura dos portos não representam um marco na história da hotelaria brasileira, muito embora as atividades mercantis tenham desencadeado

3 Com a instauração do Estado Novo, em novembro de 1937, a ditadura Vargas aumentou o peso político da cúpula militar, que se aliou à corrente industrializante dentro do governo. A partir desse momento, o Estado passou a participar diretamente do processo de industrialização. A hegemonia capitalista se instaura no Brasil a partir desta época, em que o fomento à industrialização - ou seja, da acumulação de capital industrial - passou a ser a prioridade máxima dos sucessivos governos. No Estado Novo (1937-1945), a ampliação do sistema de previdência social e da legislação do trabalho, inclusive com a concessão de algumas reivindicações do movimento operário, como a jornada de 8 horas e a instauração do salário mínimo, foram decisivas para a prática do lazer e turismo. 
um aumento na circulação de pessoas bem como um crescimento populacional que mudou as feições urbanísticas da cidade" (SANTOS, 2012, p. 93). Em passagem pela capital paulista em outubro de 1819, Saint Hilaire refere-se aos meios de hospedagem da época como bastante precários, acrescentando que a única forma de deslocamento disponível era o transporte animal, por melhor se adaptar às condições naturais das longas jornadas em terreno acidentado e em estradas que não passavam de trilhas (SAINT-HILAIRE, 1972, p. 140).

Os primeiros hotéis do Brasil surgiram no primeiro quartel do século XIX, muito embora não se possa defini-los precisamente como hospedarias ou como hotéis. Ao contrário da cidade do Rio de Janeiro, que teve um acentuado crescimento de estabelecimentos de hospedagem para atender à demanda de estrangeiros, principalmente após a Abertura dos Portos, no caso de São Paulo tal crescimento só ocorreu a partir de meados do século XIX, estimulado pelos capitais gerados pela produção cafeeira e pela implantação das estradas de ferro que faziam a ligação entre as áreas produtoras de café com o porto de Santos e com o Rio de Janeiro. Os hotéis do século XIX tinham características estruturais distintas dos estabelecimentos hoteleiros da atualidade. Além dos serviços relativos à hospedagem e à alimentação, alguns hotéis atendiam também aos eventos sociais promovidos pela sociedade da época e ao lazer proporcionado por ambientes propícios à prática do jogo. Existe uma íntima relação entre o aprimoramento dos meios de transporte e o crescimento do setor hoteleiro. Dessa forma, no início do século XIX surgiram outros estabelecimentos de hospedagem nos Estados Unidos. Em 1829, foi construído em Boston o Tremont House, um empreendimento de luxo para os padrões da época, com funcionários bem treinados, cozinha francesa, quartos muito bem mobiliados que contavam com jarras de água e ainda sabonetes de cortesia, itens considerados revolucionários naquela época (ISMAIL, 2004). De acordo com Walker (2002), o Tremont House foi o primeiro estabelecimento hoteleiro a colocar fechadura nas portas dos quartos e a empregar recepcionistas e mensageiros. No final do século XIX e no início do século XX, floresceram os hotéis grandes e luxuosos, muitos dos quais estão em atividade até hoje. A influência norte-americana generalizou-se com a expansão das cadeias hoteleiras (hotéis pertencentes a um mesmo proprietário ou empresa proprietária) na década de 1930. Conrad Hilton e Sheraton expandiram as redes americanas além de suas 
ISSN: 1983-7151

fronteiras, aumentando sua participação no plano internacional estimulada pelo crescimento dos fluxos turísticos no mundo e pela globalização dos mercados, que provocou fusões e expansões de empresas para setores com os quais tivesse complementaridade (VILLANUEVA, 2010, p. 117).

A Hilton foi a primeira rede internacional a operar no Brasil, com a inauguração do Hilton São Paulo, com 400 apartamentos, em 1971. Em 1974 instalou-se, no Rio de Janeiro, o Sheraton e o Internacional Rio, e no ano seguinte (1975) a Méridien, de origem francesa, iniciou suas atividades em Salvador. A expansão das redes internacionais e nacionais na década de 1970 está relacionada ao forte crescimento econômico no país, responsável por um expressivo crescimento das viagens de negócio e hospedagem (SANTOS, 2012, p. 120).

\section{AS ORIGENS DE BALNEÁRIO CAMBORIÚ E DO SETOR HOTELEIRO LOCAL}

O município de Balneário Camboriú/SC fica localizado no litoral norte de Santa Catarina e integra, juntamente com outros municípios, a microrregião da Foz do Rio Itajaí. É considerado o principal balneário do Sul do Brasil, recebendo na alta temporada um enorme fluxo de turistas nacionais e estrangeiros, o que estimulou a instalação de serviços urbanos, entre os quais o setor hoteleiro, para atender à demanda turística. Balneário Camboriú possui uma superfície de 46,7 $\mathrm{km}^{2}$ e conta, segundo dados do IBGE (2010), com uma população de 108.089 habitantes e uma densidade demográfica de $2.426 \mathrm{hab} . / \mathrm{km}^{2}$. Atualmente a cidade apresenta mais de seis mil estabelecimentos comerciais e mais de uma centena de empreendimentos hoteleiros (87 hotéis, segundo dados levantados junto à SECTURBC), entre hotéis, pousadas e resorts. Segundo dados da Secretaria de Estado de Turismo, Cultura e Esporte (SANTUR), Balneário Camboriú recebeu no mês de fevereiro de 2014 um total de 224.718, dos quais 191.695 nacionais e 33.023 estrangeiros. Já no mês de fevereiro de 2013, recebeu 228.191 visitantes nacionais e 46.932 estrangeiros, perfazendo 275.123 turistas. A soma do movimento de turistas da alta temporada de 2013 totalizou 628.803 visitantes e a ocupação hoteleira no período foi, em média, superior a $80 \%$, visto que conforme a SANTUR em janeiro foi de $84 \%$ e em fevereiro $78 \%$. 
Apesar de a hotelaria catarinense ser bastante diversificada e adaptada às especificidades de cada região, a maior concentração de empreendimentos hoteleiros em Santa Catarina ocorre na faixa litorânea junto às praias. O surgimento dos primeiros hotéis em Balneário Camboriú deve-se à iniciativa de descendentes de imigrantes europeus, oriundos das áreas de colonização localizadas nos vales atlânticos, sobretudo do Vale do Itajaí-Açu. O movimento de veranistas tem início na primeira metade do século passado com famílias que constroem suas segundas residências nos balneários próximos à foz do Rio Itajaí. Já na década de 1970, a melhoria do sistema rodoviário intensifica os fluxos turísticos procedentes não apenas do interior de Santa Catarina, mas também dos estados vizinhos e do exterior, especialmente da Argentina.

O município de Balneário Camboriú passou por várias transformações, desde as primeiras décadas do século $X X$, quando começou a ser procurado pelos primeiros descendentes de imigrantes europeus procedentes do vale do Rio Itajaí. Já em meados do século passado, no pós-II Guerra Mundial, quando a economia do mundo inicia um novo período de expansão, um número crescente de moradores das cidades próximas ao litoral passa a frequentar os vários balneários, promovendo a instalação de estabelecimentos comerciais e serviços, acompanhando a nova etapa do desenvolvimento capitalista do país. Cabe ressaltar que o período de 1948 a 1973 corresponde a uma nova fase expansiva do Ciclo Longo, ou Ciclo de Kontratieff, ocasião em que o centro do sistema capitalista necessita de mais matérias-primas, alimentos e mercados consumidores das regiões periféricas, levados "pelo interesse de aprofundar a divisão internacional do trabalho, bem como expandir geograficamente seu raio de atuação, incorporando inclusive novos territórios" (MAMIGONIAN, 1987, p.66). Nesta fase, para atender à expansão, são alocados grandes recursos tanto no centro como na periferia do sistema capitalista.

É nesse contexto que se dá a expansão do fluxo deveranistase, posteriormente, de turistas que promovem o surgimento e a consolidação de um aparato receptivo, dando a Santa Catarina uma posição de destaque no âmbito do turismo brasileiro. Assim sendo, para desvendar as origens e a expansão da hotelaria em Balneário Camboriú, bem como suas tendências atuais, não se podem buscar respostas apenas no plano local ou regional. A compreensão 
ISSN: 1983-7151

desse processo somente se dará se se considerar "múltiplas determinações" que vão, ao longo do tempo, atuar sobre a formação social brasileira e o desenvolvimento do capitalismo mundial.

Até 1925, conforme salienta Côrrea (1985, p.26), a Praia de Camboriú pertencente ao município de Camboriú, manteve-se praticamente deserta,

[...] emoldurada apenas por árvores e centenas de gaivotas que sobrevoavam e descansavam tranquilamente sobre as areias macias da maravilhosa praia, tão somente habitada por modestos pescadores, únicos que denotavam interesse por ela.

De acordo com Foppa (2009), "a partir de 1926, começaram a apontar no centro da praia, as primeiras casas de veraneio construídas por teuto-brasileiros vindos do Vale do Itajaí, principalmente de Blumenau, o mais importante núcleo emissor de turistas, no início do século".

Foi o povoamento teuto-brasileiro que estimulou o progresso da praia, visto que os primeiros veranistas de Balneário Camboriú, um grupo inicialmente bastante reduzido, pertenciam às classes mais abastadas do Vale do Itajaí (PEREIRA, 2003, p.117), sendo responsáveis por boa parte da infraestrutura e dos melhoramentos em vários setores, tais como o comércio e a hotelaria, para atender a essa demanda. A origem da rede hoteleira do Balneário Camboriú está relacionada à iniciativa de Jacob Alexandre Schmitt, que no ano de 1928 instalou o primeiro hotel (o Strand Hotel) construído de madeira, na confluência da atual Avenida Central com a Avenida Atlântica4, área conhecida como "saída da praia", onde se concentrava o comércio local daquela época. Aliás, grande parte das casas de veraneio construídas na antiga praia de Camboriú era de madeira procedente do Planalto Catarinense. É que diante da crise mundial decorrente da fase recessiva do segundo ciclo longo (1921-1948), alguns espaços produtivos do território nacional desvinculados da economia cafeeira, como era o caso da região coberta pela floresta de araucária no planalto serrano, foram beneficiados pela demanda interna por recursos e produtos nacionais, bem como por medidas governamentais. Abriram-se, assim, apesar

4 Cabe lembrar que, no início de década de 1920, a economia mundial se depara com um novo período de depressão do ciclo longo que se aprofunda e culmina com a grande depressão de 1929. O Brasil, como economia periférica, reage nas fases recessivas promovendo uma industrialização substitutiva de importações, como acontece durante a ditadura Vargas, que se segue à Revolução de 1930. 
das oscilações, boas perspectivas para o setor madeireiro, as quais estimularam a melhoria do escoamento da produção, até então realizada de forma precária, por meio da construção de estradas e do aparelhamento do porto de Itajaí, em razão de sua privilegiada localização geográfica. Tal fato, aliado à proximidade com o município de Itajaí, explica a utilização da madeira na construção de residências de veraneio no Balneário Camboriú. Ao ser demolido, em 1934, deu lugar ao Hotel Miramar (Figura 1), que embora tenha passado por várias transformações ainda permanece em atividade até os dias atuais.

Figura 1 - O primeiro hotel da Praia de Camboriú, de propriedade de Jacob Alexandre Schmitt, ao ser demolido em 1934 deu lugar ao antigo Hotel Miramar, construído no mesmo ano

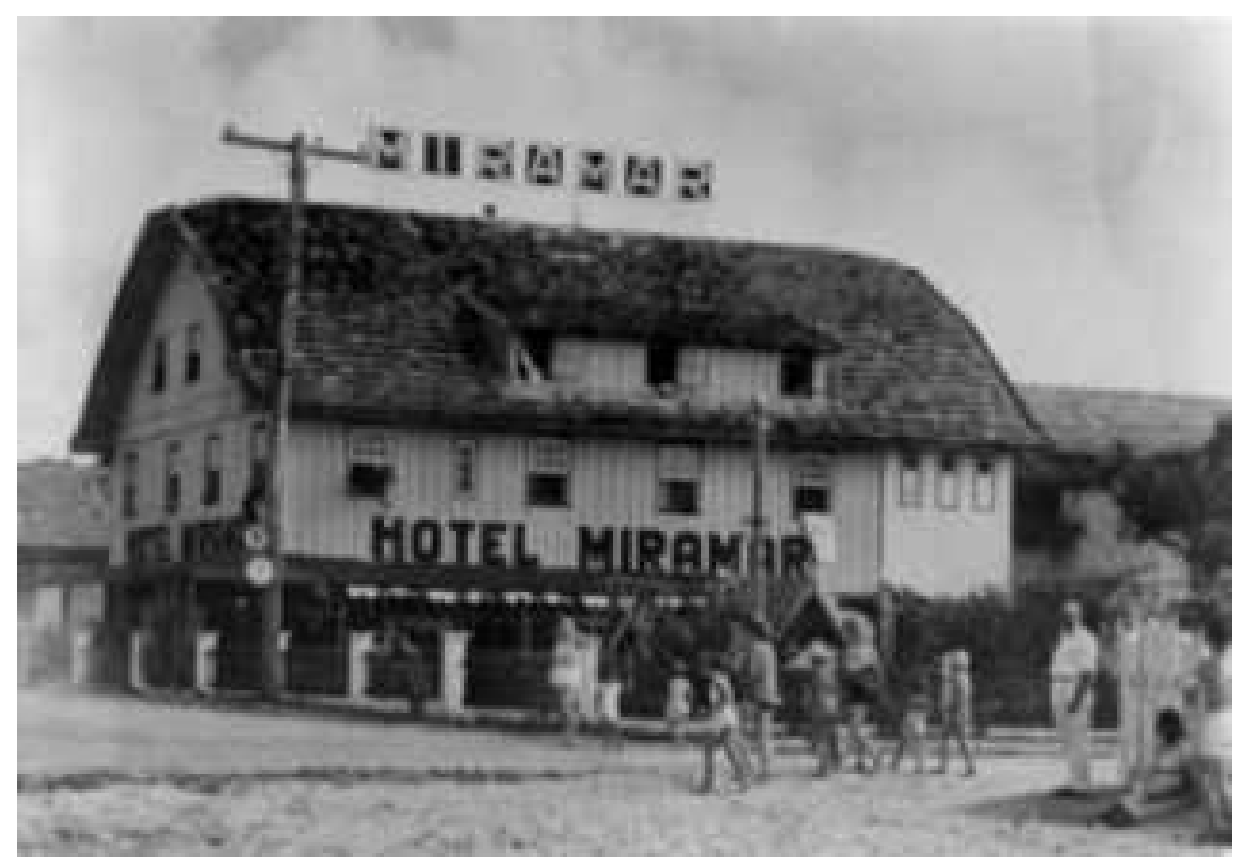

Fonte: Arquivo Histórico Municipal de Balneário Camboriú.

Nesse mesmo ano, portanto em 1934, Paulo Onckem e Lilly Onckem depois de adquirir uma propriedade de Carlos Fernandes, constroem o primeiro prédio de alvenaria da praia, o Hotel Balneário Camboriú (SANTOS, 2012, p. 223). Construído de frente para o mar (atual Av. Atlântica), foi utilizado na década de 40 como quartel general para os militares guardarem a costa brasileira, durante a participação do Brasil na II Guerra Mundial (MAUS, 2006, p. 15).

A hotelaria da então chamada Praia de Camboriú foi crescendo gradualmente ao longo dos anos, tendo estagnado durante a década de 40, em razão da Segunda Guerra Mundial. Ainda nessa mesma década, algumas famílias de 
descendentes de alemães, provenientes do Vale do Itajaí, se instalaram na Praia de Camboriú, fundando empreendimentos hoteleiros, como é o caso do Hotel Silva, fundado por Bruno Silva em 1946. Logo a viúva de Bruno Silva (Dona Rosinha Schmitt) e seus filhos diversificaram os negócios da família. Segundo Santos (2012, p.223), a família Silva, originária de Gaspar, "teve uma grande expressão no comércio local, tendo fundado também a primeira loja de confecções da praia, a Casa Silva e o Magazine Silva", além do Hotel Topázio, que permanece em atividade até hoje ${ }^{5}$.

Ainda, segundo Santos, no mesmo período, anos 40 do século passado, surgiu:

O Hotel do Baturité, de propriedade de Baturité Campos. Natural de Itapema instalou-se na praia de Camboriú, onde se tornou um importante comerciante, proprietário de um estabelecimento voltado para a salga de peixes e de uma empresa de ônibus, Auto-Viação Campos, responsável pelo transporte no trecho de Camboriú à Itajaí, na época.

Mais tarde, o Hotel Baturité foi comprado por Evaldo Benthiem, passando a se chamar Hotel Benthiem e, posteriormente, recebeu o nome de Hotel Central, após ser novamente vendido para Bruno Schroeder.

Após a emancipação de Balneário Camboriú, na década de 60 (1964), dois hotéis destacaram-se no contexto urbano do município, o Hotel Blumenau e o Hotel Marambaia. O primeiro fundado no ano de 1965, por Egon Prochnow, falecido no ano de 2005, procedente de Pomerode, casado com Fraia Gumz Prochnow. A administração desse empreendimento é familiar desde os tempos em que foi fundado até os dias de hoje, sendo que Rogério e Liane, filhos do casal, junto com a esposa do fundador, conduzem os negócios do hotel. Já o Hotel Marambaia, situado no Pontal Norte da Avenida Atlântica, de frente para o mar, foi fundado no ano de 1967. Aproveitando incentivos do governo para o turismo na região, Osmar Nunes e alguns sócios adquiriram o terreno onde hoje se encontra o hotel que representa um marco na história do município devido à sua estrutura original e inovadora. O formato circular da construção acabou

5 Segundo Álvaro Silva, filho de Bruno Silva, o empreendimento de sua propriedade funciona no mesmo prédio do antigo hotel. Sua irmã Ivone Silva Pereira, administra o Hotel Maria do Mar, localizado em Florianópolis. 
Ihe proporcionando um impressionante hall social aonde aconteciam grandes eventos frequentados por políticos, artistas e famosos da época. O Marambaia Cassino Hotel \& Convenções, já na década de 60, anunciava que a cidade seria um dos grandes polos turísticos do estado. Até os tempos atuais ele constitui um elemento de referência para a cidade. Desde então, o setor hoteleiro evoluiu constantemente, sendo marcado por inúmeros empreendimentos localizados principalmente na Praia Central do município.

O fluxo crescente de residentes e não residentes (ou seja, de veranistas e/ ou turistas) acabou estimulando a instalação de novos serviços urbanos, entre os quais a rede hoteleira, com reflexos na configuração do espaço da cidade, particularmente do seu núcleo urbano central. Em razão da especulação imobiliária e das obras de infraestrutura urbana referentes à implantação do sistema de água potável, iluminação, construção de escolas e outros equipamentos, o espaço natural foi sendo profundamente alterado, registrandose um adensamento das construções.

A paisagem urbana estava passando por grandes mudanças: se na década de 50 havia apenas casas de veraneio, dentre as quais muitas de madeira, nesse período começam a ser construídos edifícios de unidades residenciais, sendo visível o processo de verticalização. O primeiro prédio a ser construído foi o Edifício Eliane, com 4 pavimentos, seguido dos edifícios Punta del Leste, Camboriú Palace, Itapoá e Santa Inês (MAUS, 2006).

A construção da BR-101, rodovia federal que acompanha toda a orla marítima catarinense, foi decisiva para o desenvolvimento de cidades localizadas na faixa litorânea, tais como Tijucas, Biguaçu, São José e Palhoça, entre outras. Sua obra foi iniciada em 1953 e inaugurada em 1971, cortando o litoral de Santa Catarina e proporcionando o desenvolvimento de vários centros urbanos, além do aumento do fluxo de turistas. Sua extensão total é de aproximadamente 4.100 quilômetros e seu traçado segue pelo litoral brasileiro desde o estado do Rio Grande do Sul até o do Rio Grande do Norte. O trecho catarinense da BR-101 tem origem nas vias de comunicação ou caminhos que ligavam os diversos núcleos costeiros de povoamento. Ao cortar a faixa litorânea do estado, deixou à vista suas belezas até então pouco conhecidas e proporcionou o desenvolvimento de vários balneários, exercendo um papel decisivo para o 
crescimento do turismo, sobretudo na alta temporada de verão, constituindo via de escoamento para as praias catarinenses, não só de turistas estrangeiros (argentinos e uruguaios), como também de turistas procedentes de outros estados brasileiros (PEREIRA, 2013). Como principais polos turísticos no litoral de Santa Catarina, Florianópolis e Balneário Camboriú se beneficiaram não apenas com a construção da BR-101, mas também da ampliação de toda a rede rodoviária estadual, já que a grande maioria dos turistas acessa estes destinos de automóvel. Aliás, o automóvel é considerado um símbolo do capitalismo no pós-2a Guerra Mundial, instrumento por meio do qual juntamente com outras melhorias técnicas, tal como as ocorridas no setor da aviação, contribuíram para consolidar o turismo de massa a partir da segunda metade do século XX (CUNHA, 2009, p. 67) ${ }^{6}$. Cabe salientar que a segunda Revolução Industrial, ocorrida no final do século XIX, penetrou no Brasil por meio do automóvel e do caminhão, que passaram a ser importados em larga escala. Por outro lado, além da construção de rodovias ter um custo muito menor do que a de ferrovias, o investimento rodoviário é muito mais flexível (SINGER, 1986, p. 219). A estrada pode inicialmente não passar de mera trilha que será paulatinamente alargada pela passagem de caminhões e ônibus para posteriormente ser melhorada (pavimentada e/ou asfaltada).

Apesar do processo de urbanização de Balneário Camboriú ter começado com a construção de residências de veraneio (segundas residências) de famílias oriundas de cidades do Vale do Itajaí, tais como Brusque, Blumenau e Rio do Sul, cujo dinamismo industrial teve origem na colonização europeia ${ }^{7}$, a melhoria da rede rodoviária promoveu um aumento do fluxo de turistas que, por sua vez,

6 A implantação da indústria automobilística no território brasileiro, a partir de 1956, promoveu o desenvolvimento rodoviário nacional. Na década de 1960, quando a capital federal foi transferida para Brasília, as principais rodovias estavam praticamente prontas, o que estimulou a indústria automobilística nacional instalada na Região Sudeste desde de meados da década de 1950" (PEREIRA, 2013, p. 5-6).

7 O desenvolvimento industrial desses núcleos coloniais permitiu que um número significativo de pessoas dispusesse de recursos econômicos para a prática do lazer. Aliás, nos anos que se seguiram ao término da $2^{a}$ Guerra Mundial, o Brasil passou por um período de crescimento interno que, somado à expansão econômica mundial, promoveu o desenvolvimento da indústria nacional, consolidando e alargando as iniciativas de empresários, entre os quais se destacam por seu pioneirismo os industriais catarinenses, descendentes de imigrantes europeus (principalmente de alemães e italianos), localizados nos vales atlânticos, especialmente no Vale do Itajaí, de onde vieram os primeiros veranistas e empreendedores do Balneário Camboriú. 
exigiu a ampliação da rede hoteleira. Conforme relata Trigo (2003), a década de 70 foi marcada pela construção de hotéis em todo país, havendo um período de grande crescimento em função da criação da Empresa Brasileira de Turismo (EMBRATUR) em 1966, durante o governo militar, por meio do Decreto-Lei 55. O desenvolvimento de projetos hoteleiros foi bastante prejudicado pela instabilidade econômica e pelo crescimento acelerado da inflação nos anos 80 que coincide com a fase excessiva do terceiro ciclo longo iniciada com a crise do petróleo, deflagrada a partir de 1973.

\section{A HOTELARIA DO BALNEÁRIO CAMBORIÚ NA ATUALIDADE}

O processo de desenvolvimento urbano de Balneário Camboriú foi marcado por várias fases, sendo que a primeira delas está diretamente relacionada às origens deste famoso balneário do estado e se caracteriza pelo surgimento de um núcleo de veraneio para os descendentes de imigrantes provenientes das cidades do Vale do Itajaí que iniciaram a construção de "segundas residências" nas primeiras décadas do século passado. Na década de 50, ocorreu a implantação de vários loteamentos que já alcançavam a segunda quadra, acompanhando os acidentes naturais como rios, morros, ribeirões e lagoas. Em 1952, o pedido de construções encaminhado à prefeitura saltou de 58 para 620 casas, conforme informações contidas no Informativo Memória, Patrimônio, Informação (MEMPI), publicado pelo Arquivo Histórico de Balneário Camboriú. Nos anos de 1960, a partir de sua emancipação do município de Camboriú, em 1964, apesar da instabilidade política, as novas características assumidas pelo desenvolvimento do capitalismo industrial brasileiro e catarinense em especial promoveram a expansão urbana de Balneário Camboriú, a qual dinamizou, especialmente, o setor imobiliário. Depois da conturbada etapa inicial, em que houve uma sucessão de prefeitos que permaneceram à frente do poder executivo por breves períodos, a década de 1970 foi marcada por estabilidade e por obras de infraestrutura que aceleraram o processo de ocupação do espaço. Esse contexto deve ser relacionado ao cenário político e econômico nacional, marcado pela ditadura militar que se iniciara em 1964 e que nos anos de 1970 conseguirá implementar políticas de desenvolvimento que caracterizaram o chamado período do "milagre" econômico brasileiro. 
Em razão da especulação imobiliária e das obras de infraestrutura, o espaço natural foi sendo profundamente alterado, registrando-se um adensamento das construções. Ainda na década de 1970 e no início da década de 1980, houve um boom imobiliário no Balneário Camboriú, quando num período de 12 anos - 1970 a 1982 - foram aprovados 2.179.073,00 $\mathrm{m}^{2}$ de projetos a serem edificados. Paralelamente a esta expansão, ocorreram grandes alterações no sistema viário intra-urbano até então existente.

A inauguração da BR-101, aliada à ampliação da malha viária estadual, facilitou a comunicação e o acesso a diferentes regiões, imprimindo um maior dinamismo aos núcleos urbanos litorâneos de Santa Catarina. Até o início dos anos de 1970, em razão da distância e também das deficiências do sistema viário, as áreas balneárias compostas por comunidades pesqueiras e rurais se mantiveram sem grandes alterações, apesar do expressivo aumento do número de casas de veraneio, cujos proprietários pertenciam à elite catarinense. A cultura urbana do lazer e da busca por balneários, aliada à melhoria do acesso decorrente da ampliação da rede de estradas de rodagem, promoveu o crescimento das localidades situadas na faixa litorânea do estado e a intensificação do fluxo turístico. O crescente número de pessoas provenientes de outras regiões de Santa Catarina, bem como de outros estados e até mesmo de países do extremo Sul, como Argentina, Paraguai e Uruguai, estimulou a ampliação da oferta de equipamentos e serviços turísticos, tais como meios de hospedagem, alimentação, agenciamento, transporte turístico, locação de veículos, entretenimentos e comércio turístico.

Nesse mesmo período, os avanços nas obras de saneamento e infraestrutura no Balneário Camboriú contribuíram para o adensamento da população e a verticalização das construções na orla do município, sinalizando a intensificação de um processo que, nas décadas seguintes, promoveria a explosão do setor da construção civil no seu núcleo central. Os anos 80 do século passado foram marcados pelo grande fluxo de turistas argentinos, os quais tiveram uma enorme importância na turistificação do Balneário Camboriú que passa a se destacar como um dos maiores polos receptores de turistas do país. As políticas econômicas implantadas pelo governo federal nas décadas de 1980 e 1990 (Plano Cruzado, 1986; Plano Collor, 1989; Plano Real, 1994), somadas 
à legislação municipal, tiveram um papel fundamental no mercado imobiliário local, incrementando a indústria da construção civil e impondo um novo padrão de ocupação do espaço. Entretanto, foi a massificação do turismo o grande indutor da expansão urbana de Balneário Camboriú que atualmente apresenta hotéis de diversas categorias, atendendo aos mais variados tipos de público. Observa-se, contudo, que a Praia Central possui apenas um empreendimento relacionado a uma bandeira internacional, o Hotel Mercure, da rede Accor, com 291 unidades habitacionais, fruto da vinculação de uma rede hoteleira local a uma rede hoteleira internacional. A ausência de hotéis de rede pode estar relacionada ao padrão de gastos dos turistas, bem como à união entre os maiores empresários do setor hoteleiro do município que procuram, provavelmente com apoio político, manter a reserva de mercado, de modo a garantir o funcionamento de seus estabelecimentos, principalmente no período de inverno, considerado como baixa temporada. Apenas em 2012 foi inaugurado o Hotel Slaviero, da rede regional Slaviero ${ }^{8}$, situado nas proximidades de uma das saídas da cidade para a BR-101 e do Balneário Camboriú Shopping, pertencente ao grupo Almeida Junior ${ }^{9}$. Cabe destacar que, conforme Santos (2012, p.228), o mercado da construção civil em Balneário Camboriú encontra-se em plena expansão e em razão da escassez e da valorização dos terrenos, as principais construtoras têm adquirido hotéis estrategicamente localizados, mas com dificuldades para modernizar suas instalações e para manter os elevados custos operacionais (manutenção, mão de obra, impostos, etc.) para a construção de edifícios residenciais de luxo. Foi o que aconteceu recentemente com o Hotel Fisher, construído na década de 1950, adquirido pela PROCAVE Incorporadora e com o Camboriú Palace Hotel, situado na Avenida Brasil, vendido por Mário Sievert, seu proprietário, à construtora Empresa Brasileira de Edificações (EMBRAED).

A Tabela 1 demonstra que, dentre os meios de hospedagem utilizados pelos turistas que visitam Balneário Camboriú na alta temporada (jan./fev.), sobressai o aluguel de casas ou apartamentos, que abrigaram, na temporada de 2012, 37,84\% dos visitantes, enquanto que $28,18 \%$ se hospedaram em hotéis. Os hóspedes

8 A rede Slaviero tem sede em Curitiba e possui hotéis instalados no Espírito Santo (um hotel em Vitória), Mato Grosso (um em Cuiabá), Paraná (quatro hotéis: Curitiba, São José dos Pinhais, Foz do Iguaçu e Ponta Grossa), Santa Catarina (quatro: Florianópolis, Balneário Camboriú, Joinville e Palhoça) e em São Paulo (três: São Paulo, Guarulhos e São Carlos).

9 Fundado em Blumenau em 1980, é a maior empresa regional de Shopping Centers do Brasil. Dos 18 shoppings localizados nas cidades litorâneas catarinenses, cinco pertencem ao grupo Almeida Junior. 
do setor hoteleiro, mesmo somados aos 2,32\% que se instalaram em pensões e dormitórios e aos 1,55\% de pousadas, representa um total de 32,05\%, ou seja, um percentual inferior ao dos que se utilizam do aluguel de casas ou apartamentos.

Tabela 1: Meios de Hospedagem Utilizados em Balneário Camboriú na alta temporada

\section{Balneário Camboriú Jan/Fev 2012}

\section{9 - MEIOS DE HOSPEDAGEM UTILIZADOS}

\begin{tabular}{llr}
\hline MEIO DE HOSPEDAGEM & jan $^{*}$ & fev \\
\hline CASA OU APTO. ALUGUEL & - & $37,84 \%$ \\
HOTEL & - & $28,18 \%$ \\
CASA AMIGOS/PARENTES & - & $15,44 \%$ \\
CASA PRÓPRIA & - & $14,67 \%$ \\
HOSP JPENSÃO/DORMIT. & - & $2,32 \%$ \\
POUSADA & - & $\mathbf{1 , 5 5 \%}$ \\
ALBERGUE/ALOJAMENTO & - & - \\
CAMPING & - & - \\
TOTAL & & $\mathbf{1 0 0 , 0 0 \%}$
\end{tabular}

fonte: SANTUR/GERENCIA DE PLANEJAMENTO

O Quadro 1 apresenta uma listagem dos empreendimentos hoteleiros de Balneário Camboriú em atividade, com os seus respectivos nomes, ano de fundação, proprietários e administração vigente, desde o surgimento do primeiro hotel na década de 20. Cabe destacar que os dados obtidos por meio de solicitação à Prefeitura Municipal apontaram a existência de um total de 72 hotéis e 20 pousadas registradas oficialmente, o que demonstra uma divergência nos registros existentes sobre o setor hoteleiro em diferentes fontes de consulta.

Quadro 1 - Lista de empreendimentos hoteleiros do Balneário Camboriú

\begin{tabular}{|c|c|c|c|c|c|}
\hline NOME & FUNDAÇÃO & PROPRIETÁRIO & \begin{tabular}{|c|} 
ADMINISTRA- \\
ÇÃO
\end{tabular} & ENDEREÇO & $\begin{array}{l}\text { NÚMERO } \\
\text { DE UH's }\end{array}$ \\
\hline \multicolumn{6}{|c|}{ Empreendimentos Hoteleiros - Década de 30} \\
\hline Hotel Miramar & 1930 & Luiz DellmarRotilli & Familiar & Av. Central, 25 & 161 \\
\hline \multicolumn{6}{|c|}{ Empreendimentos Hoteleiros - Década de 60} \\
\hline HM Plaza Hotel & 1960 & Hélio Marques & Familiar & R. 1901,291 & 360 \\
\hline $\begin{array}{c}\text { Marambaia Cassino } \\
\text { Hotel }\end{array}$ & 1964 & 4 Proprietários & $\begin{array}{l}\text { Não familiar } \\
\text { (desde 2010) }\end{array}$ & Av. Atlântica, 300 & 126 \\
\hline Hotel Blumenau & 1965 & $\begin{array}{l}\text { Mais de um } \\
\text { proprietário }\end{array}$ & Familiar & R. 1001,129 & 114 \\
\hline
\end{tabular}


DoI: 10.14210/rtva.v17n2.p508-537

\begin{tabular}{|c|c|c|c|c|c|}
\hline Hotel Paraná & 1965 & $\begin{array}{l}\text { Avelina Luiza } \\
\text { Ferreira e André } \\
\text { Luiz Ferreira }\end{array}$ & Familiar & R. 901,415 & 18 \\
\hline Hotel Itália & 1965 & Elisana Schneider & Sociedade & R. 1500,110 & 54 \\
\hline Hotel San Remo & $\begin{array}{l}1968 \text { (Pertence } \\
\text { à rede Candeias } \\
\text { desde 2013) }\end{array}$ & $\begin{array}{c}\text { José de Carvalho } \\
\text { Monteiro }\end{array}$ & Não Familiar & Av. Atlântica, 270 & 113 \\
\hline Viviane Hotel & $\begin{array}{c}1968 \\
\begin{array}{c}\text { (Pertence à rede } \\
\text { Candeias) }\end{array} \\
\end{array}$ & $\begin{array}{c}\text { Monteiro Carvalho } \\
\text { e sócios }\end{array}$ & Não familiar & $\begin{array}{l}\text { R. Isidoro Caetano, } \\
20 \text { - Pioneiros }\end{array}$ & 80 \\
\hline \multicolumn{6}{|c|}{ Empreendimentos Hoteleiros - Década de 70} \\
\hline Hotel Melo & 1970 & $\begin{array}{c}\text { Alba Ramos de } \\
\text { Melo }\end{array}$ & Familiar & Av. Brasil, 2195 & 45 \\
\hline Hotel Pires & 1970 & Joel Rogério Pires & $\begin{array}{l}\text { Rede Pires de } \\
\text { Hotelaria }\end{array}$ & Av. Brasil, 1725 & * \\
\hline Hotel Gumz & 1971 & $\begin{array}{l}\text { Carmen Gunz e } \\
\text { Ingo Gunz }\end{array}$ & Familiar & R. 1200,140 & 80 \\
\hline Puçá Hotel & 1973 & Maria Augusta & Familiar & R. 1101,259 & 44 \\
\hline Hotel Gracher & 1973 & $\begin{array}{c}\text { Carlos Gracher } \\
\text { Neto }\end{array}$ & Familiar & Av. Brasil, esq. 3300 & 130 \\
\hline Hotel Shallom & 1979 (aprox.) & $\begin{array}{l}\text { Eunice Vicente } \\
\text { Franzoi }\end{array}$ & Familiar & R. Panamá, 36 & 21 \\
\hline $\begin{array}{c}\text { Hamburgo Palace } \\
\text { Hotel }\end{array}$ & $\begin{array}{l}\text { Aprox. } 40 \text { anos } \\
\text { (1979) }\end{array}$ & José Kleine & Familiar & R. 1901, 333 & 162 \\
\hline \multicolumn{6}{|c|}{ Empreendimentos Hoteleiros - Década de 80} \\
\hline Hotel Dinamarca & 1980 & Mafalda Poffo & Familiar & R. Dinamarca, 27 & 22 \\
\hline Camboriú Hotel & 1980 & Heliete M. Pereira & Familiar & Av. do Estado, 5029 & 22 \\
\hline Candeias II & 1982 & $\begin{array}{c}\text { José de Carvalho } \\
\text { Monteiro }\end{array}$ & Não é familiar & $\begin{array}{c}\text { Av. do Estado, } 3860 \\
\text { - Centro }\end{array}$ & 45 \\
\hline Hotel San Carlos & 1982 & $\begin{array}{l}\text { Nivaldo Teodoro } \\
\text { Wvessling }\end{array}$ & Familiar & Av. do Estado, 3468 & 36 \\
\hline Marimar - The Place & 1982 & Mario Luiz Preto & Familiar & Av. Brasil, 1091 & 90 \\
\hline Ryan Hotel & 1983 & Joel Rogério Pires & $\begin{array}{l}\text { Rede Pires de } \\
\text { Hotelaria }\end{array}$ & Av. Central, 128 & 64 \\
\hline Hotel Negrini & $\begin{array}{l}\text { Aprox. } 30 \text { anos } \\
\text { (1984) }\end{array}$ & Nedi Flor Maciel & Familiar & R. 3300,45 & 90 \\
\hline Hotel Geranium & $\begin{array}{l}\text { Aprox. } 30 \text { anos } \\
\text { (1984) }\end{array}$ & Dirce Fiastarou & Familiar & Av. Brasil, 2970 & 88 \\
\hline Hotel Gênova & 1985 & Ana Benvenutti & Familiar & R. 3700,160 & 80 \\
\hline Hotel Cottone & 1986 & $\begin{array}{l}\text { Espolio de } \\
\text { Salvatore Cottone }\end{array}$ & Familiar & BR 101, km 136 & 190 \\
\hline Hotel Topázio & 1986 & Álvaro Silva & Familiar & R. 11,15 & 47 \\
\hline Hotel dos Açores & $\begin{array}{l}\text { Aprox. } 25 \text { a } 30 \text { anos } \\
\quad(1989-1984)\end{array}$ & $\begin{array}{l}\text { José Amilton de } \\
\text { Oliveira }\end{array}$ & Familiar & Av. Brasil, 1747 & 184 \\
\hline
\end{tabular}


ISSN: 1983-7151

\begin{tabular}{|c|c|c|c|c|c|}
\hline Ilha da Madeira & 1987 & $\begin{array}{l}\text { José Amilton de } \\
\text { Oliveira }\end{array}$ & $\begin{array}{l}\text { Rede Sagres } \\
\text { de Hotelaria }\end{array}$ & Av. Brasil, 1590 & 199 \\
\hline HM Praia Hotel & $\begin{array}{l}\text { Aprox. } 30 \text { a } 40 \text { anos } \\
(1979-89)\end{array}$ & Hélio Marques & Familiar & R. 1931, 201 & 51 \\
\hline Jaistur Hotel & 1988 & $\begin{array}{c}\text { Gilberto Borba } \\
\text { Corrêa }\end{array}$ & Familiar & Av. Sta. Catarina, 444 & 24 \\
\hline Barra Sul Hotel & $\begin{array}{c}1989 \text { (Comprado } \\
\text { novamente em } \\
\text { 2008) }\end{array}$ & $\begin{array}{c}\text { Agostinho Ferreira } \\
\text { Filho }\end{array}$ & Familiar & R. 4000,85 & 98 \\
\hline \multicolumn{6}{|c|}{ Empreendimentos Hoteleiros - Década de 90} \\
\hline $\begin{array}{l}\text { Hotel Costa do } \\
\text { Marfim }\end{array}$ & 1991 & Joel Rogério Pires & $\begin{array}{l}\text { Rede Pires de } \\
\text { Hotelaria }\end{array}$ & R. 1500,310 & 111 \\
\hline Hotel Villa do Mar & $\begin{array}{l}1991 \text { (ou aprox. } \\
\text { 20anos) }\end{array}$ & Lurdes Ammann & Familiar & Av. Atlântica, 2420 & 84 \\
\hline Palmas Palace Hotel & 1991 (1994 iniciou) & * & Familiar & R. São Paulo, 56 & 60 \\
\hline Centromar Hotel & 1992 & Pedro Pereira & Familiar & Av. Central, 426 & 126 \\
\hline Sibara Flat Hotel & 1992 & $\begin{array}{l}\text { Famílias Testoni e } \\
\text { Figueredo }\end{array}$ & Grupo Sibara & Av. Brasil, 1500 & 203 \\
\hline $\begin{array}{l}\text { Apart Hotel do } \\
\text { Bosque }\end{array}$ & 1992 & Fernando Bernard & Familiar & Av. Brasil, 22 & 32 \\
\hline Pecon Hotel & 1993 & Nelson Nitz & Familiar & Av. Brasil, 477 & 87 \\
\hline Novo Hotel Douglas & Comprado em 1993 & $\begin{array}{l}\text { filho de: Hugo Raul } \\
\text { Segundo González }\end{array}$ & Familiar & Av. do Estado, 3125 & 31 \\
\hline Hotel Sagre's & $\begin{array}{l}\text { Aprox. } 20 \text { à 25anos } \\
\quad(1994-1989)\end{array}$ & José Oliveira & Não Familiar & Av. Central, 159 & 98 \\
\hline Vieira's Hotel & $\begin{array}{c}\text { Aprox. } 20 \text { anos } \\
(1994)\end{array}$ & José Wilson Vieira & Familiar & $\begin{array}{c}\text { Av. do Estado/ R. } \\
\text { México }\end{array}$ & 144 \\
\hline $\begin{array}{l}\text { Hotel Prime } \\
\text { Tropikalya }\end{array}$ & 1994 & Rita de Cássia & Familiar & R. 401,15 & 30 \\
\hline Hotel Luz do Sol & 1995 & $\begin{array}{l}\text { Maria José Melo } \\
\text { Machado }\end{array}$ & Familiar & R. 951, 379 & 18 \\
\hline Atobá Praia Hotel & 1997 & Joel Rogério Pires & $\begin{array}{c}\text { Rede Pires de } \\
\text { Hotelaria }\end{array}$ & Av Brasil, 3080 & 120 \\
\hline Arlene Palace Hotel & 1997 & ArleneDellatorre & Familiar & * & * \\
\hline $\begin{array}{l}\text { Hotel Plaza } \\
\text { Camboriú }\end{array}$ & 1997 & Carmem Peters & Familiar & Av. Brasil, 1410 & 169 \\
\hline Royal Atlantic Hotel & 1999 & $\begin{array}{l}\text { Anselmo de Souza } \\
\text { e Darci Nicareta }\end{array}$ & - & * & * \\
\hline Parnaso Hotel & 1999 & $\begin{array}{c}\text { Darci Paulo } \\
\text { Nicaretta e } \\
\text { Antonio Benneti }\end{array}$ & Familiar & Av. Central, 321 & 80 \\
\hline \multicolumn{6}{|c|}{ Empreendimentos Hoteleiros - A partir de 2000/ Sem Informação } \\
\hline Mar Hotel & 2000 & Milesio Leal & Familiar & R. 701,275 & 101 \\
\hline Hotel Torresol & 2000 & $\begin{array}{c}\text { Empresa Derudder } \\
\text { Hermanos CRL }\end{array}$ & Familiar & Av. do Estado, 2699 & 93 \\
\hline
\end{tabular}


DoI: 10.14210/rtva.v17n2.p508-537

\begin{tabular}{|c|c|c|c|c|c|}
\hline Hotel Felissimo & 2001 & $\begin{array}{l}\text { Roberto e Graça } \\
\text { Schauffert }\end{array}$ & Familiar & $\begin{array}{l}\text { R. Alles Blau, } 201 \text { - } \\
\text { Praia Dos Amores }\end{array}$ & 10 \\
\hline Hotel D'Sintra & 2001 & $\begin{array}{l}\text { Edson César de } \\
\text { Oliveira }\end{array}$ & Familiar & Av. Atlântica, 1040 & 207 \\
\hline Hotel Suíça & $\begin{array}{l}\text { Aprox. } 15 \text { anos } \\
\text { (2001) }\end{array}$ & Roger Faber & Familiar & R. 3144,10 & 86 \\
\hline Hotel das Américas & $\begin{array}{l}\text { Aprox. } 10 \text { a } 15 \text { anos } \\
(2004-1999)\end{array}$ & $\begin{array}{l}\text { Fernanda } \\
\text { Dellatorre }\end{array}$ & Familiar & R. 501,111 & 96 \\
\hline $\begin{array}{c}\text { Costa Sul Beach } \\
\text { Hotel }\end{array}$ & 2003 & $\begin{array}{l}\text { Mário Giacomini } \\
\text { Ribas }\end{array}$ & Familiar & Av. Alvin Bauer, 379 & 132 \\
\hline Prince Apart Hotel & $\begin{array}{c}2004 \text { (ano em que } \\
\text { o atual proprietário } \\
\text { assumiu) }\end{array}$ & $\begin{array}{l}\text { Paulinho Luiz } \\
\text { Barcella }\end{array}$ & Familiar & $\begin{array}{l}\text { R. } 3500,175- \\
\text { Centro }\end{array}$ & 19 \\
\hline Hotel Rosembrock & 2005 & Valdir Rosembrock & Familiar & R. Holanda, 195 & 84 \\
\hline $\begin{array}{c}\text { Parador Estaleiro } \\
\text { Hotel }\end{array}$ & 2006 & Daniela Sense & Sociedade & Estaleirinho & 16 \\
\hline $\begin{array}{l}\text { Hotel Bella } \\
\text { Camboriú }\end{array}$ & 2006 & Margo Rosenbrock & Familiar & R. 501,30 & 84 \\
\hline $\begin{array}{l}\text { Mercure Camboriú } \\
\text { Internacional }\end{array}$ & 2007 & Joel Rogério Pires & $\begin{array}{l}\text { Rede Pires de } \\
\text { Hotelaria }\end{array}$ & Av. Atlântica, 2010 & 201 \\
\hline Sanfelice Hotel & 2007 & Edson Sanfelice & Familiar & R. 1922,110 & 110 \\
\hline Charlote Cabanas & 2010 & Via Mar Turismo & $\begin{array}{l}\text { Associação de } \\
\text { Tur. Via Mar }\end{array}$ & $\begin{array}{l}\text { R. Islândia, } 101 \text { - } \\
\text { Centro }\end{array}$ & 12 \\
\hline -- Hotel Interpraias & 2010 & $\begin{array}{l}\text { Paulinho Luiz } \\
\text { Barcella }\end{array}$ & Familiar & Av. Interpraias, 10 & 15 \\
\hline $\begin{array}{c}\text { Infinity Blue Resort } \\
\& \text { Spa }\end{array}$ & $\begin{array}{l}2011 \text { (ano em que } \\
\text { foi adquirido pelo } \\
\text { Grupo Embraed) }\end{array}$ & Tatiana Rosa & Familiar & $\begin{array}{l}\text { Estrada da Rainha, } \\
\qquad 800\end{array}$ & 122 \\
\hline Hotel Slaviero Slim & 2012 & Renato Campos & Rede & $\begin{array}{l}\text { Av. Santa Catarina, } \\
1000\end{array}$ & 108 \\
\hline Hotel Visual III & $\begin{array}{l}\text { *Não souberam } \\
\text { informar (Comprado } \\
\text { em 2013) }\end{array}$ & $\begin{array}{l}\text { Mário Luiz Anonio } \\
\text { Lima }\end{array}$ & Familiar & Av. do Estado, 1650 & 32 \\
\hline $\begin{array}{l}\text { Hotel Gold } \\
\text { Tropikalya }\end{array}$ & $\begin{array}{l}\text { *Não souberam } \\
\text { informar }\end{array}$ & Rita de Cássia & Familiar & R. 401,94 & * \\
\hline Hotel Praiamar & $\begin{array}{l}\text { *Não souberam } \\
\text { informar }\end{array}$ & José Luiz Gomez & Familiar & R. 2000,300 & 60 \\
\hline Hotel Rieger & * & * & * & R. 701,162 & * \\
\hline Hostel Rezende & * & * & * & R. 3100,780 & * \\
\hline Master Hotel & * & * & * & R. 1650,40 & * \\
\hline $\begin{array}{l}\text { Hotel Tropical } \\
\text { Summer }\end{array}$ & ** & ** & ** & R. 4100,100 & ** \\
\hline Hotel Sol & ** & ** & ** & Av. do Estado, 3906 & ** \\
\hline
\end{tabular}


ISSN: 1983-7151

\begin{tabular}{|c|c|c|c|c|c|}
\hline Ilha do Sol & ** & ** & ** & $\begin{array}{l}\text { R. Israel, } 70 \text { - Bairro } \\
\text { das Nações }\end{array}$ & ** \\
\hline San Marco & * & * & * & $\begin{array}{l}\text { R. Julieta Lins, } 429 \text { - } \\
\text { Pioneiros }\end{array}$ & 38 \\
\hline Hotel Bhaly & * & * & * & Av. Atlântica, 3250 & * \\
\hline Hotel Sandri City & * & * & * & $\begin{array}{l}\text { R. } 1400,160- \\
\text { Centro }\end{array}$ & * \\
\hline $\begin{array}{c}\text { San Marino Cassino } \\
\text { Hotel }\end{array}$ & * & * & * & R. 1919, 44 - Centro & * \\
\hline
\end{tabular}

* Preferem não divulgar

** Não está em funcionamento

Fonte - Dados coletados in loco ou via telefone, a partir da listagem de hotéis do site da Secretaria de Turismo de Balneário Camboriú. (Elaborada pela autora).

Com a liberação do trecho da BR-101, que ligava Itajaí a Itapema, o município teve o desenvolvimento do turismo acentuado e, em consequência, crescem a sua população e o setor da construção civil. Nessa mesma década, foram fundados mais alguns empreendimentos hoteleiros, como, por exemplo: Hotel Pires, Hotel Gunz e Hotel Gracher. Ainda hoje, esses três hotéis continuam em atividade.

O Hotel Pires, localizado na Avenida Brasil, a trinta metros da Avenida Central, iniciou suas atividades no ano de 1970, quando Joel Rogério Pires, procedente de São Joaquim (cidade localizada no Planalto Catarinense) ${ }^{10}$, com objetivo de progredir e aumentar seus recursos financeiros, aplicou seu capital na construção do estabelecimento. Seu investimento deu tão certo nessa época, que treze anos após o primeiro empreendimento, inaugurou na Avenida Central (antigamente conhecida como a Saída da Praia), no ano de 1983, o Hotel Ryan. Atualmente, o empresário possui quatro estabelecimentos hoteleiros, os quais compõem uma rede, conhecida internacionalmente por Rede Pires de Hotéis, estando em fase de acabamento mais um hotel que fará parte dessa rede. 0 novo empreendimento está localizado na Avenida Atlântica, próximo à Praça Almirante Tamandaré. Mesmo com um número considerável de funcionários, a administração dos empreendimentos permanece em poder da família, sendo que o patriarca divide seu comando com a esposa e os filhos.

10 De acordo com Pereira e Maus (2006), Joel Rogério Pires e Antonieta Vaz Sepetiba Pires são pais de: Joel Rogério Pires Júnior e Isaac Vaz Sepetiba Pires. Ambos os filhos, além de administrar a rede de hotéis, possuem outras empresas. Uma delas corresponde a uma franquia da Multinacional Mc Donald's, que Joel R. Pires Junior trouxe para Balneário Camboriú, abrindo o primeiro Restaurante em 1995, que mais tarde (ano 2000) vendeu à Corporação Mc Donald's. Já Isaac Pires possui até hoje restaurantes da mesma rede em Florianópolis, um deles no Shopping Itaguaçu em São José. 
O Hotel Gunz, localizado na Rua 1200, iniciou suas atividades em $1^{\circ}$ de março de 1971, tendo como fundadores Ingo Gunz e sua esposa Carmen Gunz, vindos do município de Pomerode. Atualmente a administração desse hotel é feita pela senhora Carmen Gunz, em parceria com seus filhos Jorge e Vera Gunz, marcando mais um empreendimento hoteleiro de administração familiar fundado por descendentes de alemães vindos do Vale do Itajaí, área de colonização com uma pequena produção mercantil que permitiu a acumulação de capital necessário inicialmente ao desenvolvimento comercial e posteriormente industrial e no encadeamento favoreceu a expansão do setor de serviços, como os ligados ao turismo e à hotelaria, em particular.

O Hotel Gracher, empreendimento também precursor desse período, foi fundado no ano de 1973, por Carlos Gracher, natural de Brusque. Caracterizase também por um hotel com administração vigente familiar. Um dos auxiliares dessa administração e proprietário do hotel é Carlos Gracher Neto, de 54 anos.

Dentre os hotéis citados na Tabela 2, observa-se que, além da Rede Pires de Hotéis, há mais duas Redes de Administração Hoteleira: a Rede Sagre's de Hotéis $^{11}$ e o Grupo Sibara. A primeira rede possui mais de 20 anos, tendo sido o seu empreendimento precursor o Sagre's Praia Hotel, localizado na Avenida Central. Essa mesma rede possui mais cinco estabelecimentos hoteleiros, sendo eles: Florianópolis Palace Hotel, na capital do estado, Florianópolis; Hotel Catamarã; Hotel dos Açores; Hotel Ilha da Madeira e Hotel D'Sintra, situados na Praia Central de Balneário Camboriú. O último deles é o mais novo empreendimento da rede que tem todos os hotéis controlados pelo proprietário e a administração familiar. Cabe salientar que o Hotel dos Açores, com 184 unidades habitacionais e o Sagres Praia Hotel, com 98, são mantidos em funcionamento apenas na alta temporada.

O Grupo Sibara é proprietário do Sibara Flat Hotel ${ }^{12}$, sendo administrado

11 José Amilton de Oliveira é o proprietário da Rede Sagre's de Hotéis.

12 O Hotel representa um dos estabelecimentos pertencentes ao Grupo Sibara, integrado por Postos de Combustível, Motel 2001, Lojas Sibara (Itajaí, Balneário Camboriú, Joinville e Florianópolis), além de atuar ainda em operações portuárias na cidade de Itajaí e no ramo da construção civil por meio de uma construtora em sociedade com Luiz Alves Mendes (Mendes Sibara Engenharia Ltda). Em 2009, o grupo passou a investir também no ramo dos Shoppings Centers, inaugurando o Via Catarina Shopping, no município de Palhoça. O Grupo Sibara também atua em operações portuárias na cidade de Itajaí. 
por duas famílias: a família Testoni, de Itajaí e a família Figueredo, procedente de Portugal. O empreendimento hoteleiro do grupo foi fundado em 1992. Seu edifício, com 17 pavimentos, localiza-se na Avenida Brasil, próximo à Avenida Central. Uma curiosidade descoberta ao longo de uma entrevista realizada foi a de que o prédio não possui a marcação de um $13^{\circ}$ andar, uma característica bastante peculiar demonstrada pela superstição de um dos proprietários.

A partir do levantamento de dados de alguns empreendimentos hoteleiros da Praia Central de Balneário Camboriú, foi constatado que muito dos hotéis existentes na cidade foram fundados e pertencem, ainda nos dias de hoje, a famílias de descendentes de alemães procedentes do Vale do Itajaí que se instalaram na atual Praia Central de Balneário Camboriú. Outro fato a ser registrado diz respeito à distribuição espacial dos hotéis do Balneário Camboriú a qual apresenta uma nítida concentração na Avenida Central e seus arredores, muito embora o desenvolvimento da atividade turística tenha promovido a sua expansão especialmente ao longo das Avenidas Atlântica e Brasil, além da Avenida do Estado. Dentre os mais recentes empreendimentos hoteleiros da cidade, podem-se destacar os hotéis Charlote Cabanas (2010), Interpraias (2010), Slaviero Slim (2012), todos inaugurados nessa ultima década. Por fim, cabe salientar que a grande maioria dos hotéis locais permanece ainda sob a administração de seus fundadores ou de seus descendentes diretos, como é o caso do Hotel Blumenau, do Hotel Mello, do Hotel Pires e do Hotel Gumz, todos com mais de 40 anos de funcionamento.

\section{CONSIDERAÇÕES FINAIS}

Ao analisar as origens do setorhoteleiro do Balneário Camboriú ficou comprovada sua relação direta com a acumulação de pequenos capitais obtidos por meio da pequena produção mercantil extremamente dinâmica das áreas de colonização do território catarinense, ocupadas em meados do século XIX por imigrantes de origem europeia. As iniciativas pioneiras da hotelaria foram de empreendedores oriundos, sobretudo, do Vale do Itajaí e sua evolução está fortemente vinculada às diferentes etapas do desenvolvimento socioeconômico brasileiro, inserido no contexto internacional. Diante de tais constatações, foi possível perceber a validade 
do referencial teórico utilizado no desenvolvimento da pesquisa e das categorias de análise aplicadas ao estudo da realidade catarinense.

A evolução do setor e o expressivo número de empreendimentos hoteleiros do Balneário Camboriú devem-se à sua consolidação como destino turístico de lazer, o que favoreceu o crescimento não apenas da hotelaria, mas também de estabelecimentos ligados à alimentação, ao lazer e ao entretenimento, gerando empregos e criando novos postos de trabalho. A economia do município atualmente gira em torno de atividades ligadas ao comércio e ao turismo e para o seu desenvolvimento foi fundamental a expansão da rede rodoviária nacional e estadual que facilitou o acesso de fluxos turísticos procedentes de outras regiões do território catarinense, de outros estados brasileiros e até mesmo internacionais, sobretudo da Argentina. Os anos de 1970 representam um marco nessa evolução em decorrência, especialmente, da inauguração da BR-101 que acabou por revelar as belezas do litoral catarinense até então pouca conhecidas. Essa importante rodovia federal acabou promovendo o crescimento da atividade turística e da construção civil no município que hoje se destaca, não somente no cenário estadual, como também no nacional pela altura de seus edifícios. Essa dinâmica provocou uma ocupação intensa e descontrolada do espaço urbano, sem que houvesse um sistema de planejamento e de controle desse crescimento. A magnitude da demanda turística acabou gerando o desenvolvimento econômico do município que até os dias atuais tem no turismo sua principal fonte de renda.

A investigação demonstrou que diante da presença maciça de hotéis independentes, principalmente familiares, é inexpressivo o número de estabelecimentos de redes hoteleiras internacionais, nacionais e regionais. Foi detectada a presença de redes hoteleiras locais, tais como a Rede Pires e a Rede Sagres, cujas filiais estão situadas, de um modo geral, na própria cidade e administradas por integrantes da família dos proprietários. Essa característica marcante da hotelaria de Balneário Camboriú soma-se ao fato de que a grande maioria dos hotéis em atividade permanece ainda em poder das famílias que os fundaram. Atualmente percebe-se que a maioria dos hotéis está com sua estrutura física ultrapassada. Por essa razão, aliada à sazonalidade da ocupação nos estabelecimentos hoteleiros e à reduzida disponibilidade de terrenos, o 
ISSN: 1983-7151

setor da construção civil está em constante busca por terrenos bem localizados, como é o caso daqueles ocupados pela hotelaria. É nesse cenário que alguns dos antigos hotéis acabaram sendo adquiridos por grandes construtoras que, após a demolição, irão construir luxuosos edifícios residenciais.

O turismo de negócios e de eventos é atualmente a principal força para o setor hoteleiro catarinense como forma de minimizar os efeitos negativos da sazonalidade, muito embora exista ainda uma carência de estruturas capazes de atender a eventos de grande porte.

\section{REFERÊNCIAS}

ARQUIVO HISTÓRICO DE BALNEÁRIO CAMBORIÚ, Informativo MEMPI: Memória Patrimônio - Informação. Ano 04 Edição 05. Balneário Camboriú: Arquivo Histórico de Balneário Camboriú, Junho 2009.

CAMPOS J.R.V. Introdução ao universo da hospitalidade. Campinas: Papirus, 2005

CANDIDO, I.; VIEIRA, E. Gestão de Hotéis: técnicas, operações e serviços. Caxias do Sul: Educs, 2003.

CASTELLI, G. Hospitalidade na Perspectiva da Hotelaria e da Gastronomia. São Paulo: Saraiva, 2005.

CORRÊA, Isaque de Borba. História de duas cidades: Camboriú e Balneário Camboriú. Gráfica Camboriú. 1985.

CUNHA, D. R. (2009). A Rodovia BR 101 - Sul (Trecho entre Palhoça, São José e Acesso à Florianópolis): Desenvolvimento Regional e turismo na Grande Florianópolis. Dissertação de Mestrado (Mestre em Turismo e Hotelaria) - Mestrado Acadêmico em Turismo e Hotelaria, Universidade do Vale do Itajaí, Balneário Camboriú, p.164.

FOPPA, Carina Catina. Comunidades pesqueiras e a construção de territórios sustentáveis na zona costeira: uma leitura a partir da área de proteção ambiental da costa Brava em Balneário Camboriú/SC. (2009, 100f.) Dissertação (Mestrado Profissionalizante em Planejamento Territorial e Desenvolvimento Sócio-Ambiental).a Florianópolis - SC, UDESC, 2009.

HOTEL MARAMBAIA. Descubra o Marambaia. Disponível em: <"http://www.marambaia. com.br/hotel/marambaia" >. Acesso em: Junho de 2014. 
IBGE - Instituto Brasileiro de Geografia e Estatística, Estimativa de população. Disponível em: <"ftp://ftp.ibge.gov.br/Estimativas_de_Populacao/Estimativas_2013/estimativa_2013_ dou.pdf">. Acesso em: 18 de fevereiro de 2014.

ISMAIL, A. Hospedagem: front Office e Governança. São Paulo: Pioneira Thomsom Learning, 2004.

MAMIGONIAN, A. Introdução ao Pensamento de Inácio Rangel. In: Revista GeoSul, v. 02, n. 03. Florianópolis/SC: UFSC, 1987.

MAMIGONIAN, A. Portos e Navegação Marítima no Brasil. ENCONTRO DE GEÓGRAFOS DA AMÉRICA LATINA, XIV, 2013, Lima (Peru). Anais... Lima (Peru): EGAL, 2013. p. 1-5.

MAUS, Isabel Cristina. Diagnóstico do Setor Hoteleiro na Praia Central de Balneário Camboriú (SC): Passado e Presente. Relatório Final de Pesquisa - PIBIC/CNPq. Curso de Arquitetura e Urbanismo da Universidade do Vale do Itajaí. UNIVALI, Balneário Camboriú, 2006.

MONTEIRO, Carlos Augusto de Figueiredo. Clima. CATALDO, Delnida Martinez (Org.). Geografia do Brasil: Grande Região Sul. Vol. IV, Tomo I. Rio de Janeiro: IBGE, 1963.

MONTEJANO, J. M. Estrutura do mercado turístico. São Paulo: Roca; 2001.

PEREIRA, R. M. F. A. Sistema rodoviário e turismo no litoral do estado de Santa Catarina Brasil. In: Revista TURyDES, v. 06, n. 15. Málaga, dez. 2013.

PIRES, Mário Jorge. Raízes do Turismo no Brasil. São Paulo: Editora Manole, 2001, 236p

SAINT-HILAIRE, A. Viagem à Província de São Paulo. São Paulo: Universidade, 1972.

SANTOS, Fabiola Martins dos. Geografia das Redes Hoteleiras: Mundo, Brasil e Santa Catarina. 2012. 397p. Tese (Doutorado em Geografia) - Universidade Federal de Santa Catarina, Florianópolis, SC, 2012.

SANTOS, Milton. Espaço e Sociedade: ensaios. 2. ed. Petrópolis: Vozes, 1982.

SANTUR - Santa Catarina e Turismo S/A, Estudo da Demanda Turística, Alta Estação 2013. Disponível em: <"http://www.santur.sc.gov.br/estatistica-do-turismo-catarinense-santur. html" >. Acesso em: 25 de março de 2014.

SECTURBC-Secretaria de Turismo de Balneário Camboriú. Hospedagem. Disponível em <"http://www.secturbc.com.br/"> . Acesso em: Outubro de 2013 e Fevereiro de 2014. 
SINGER, Paul. Interpretação do Brasil: uma experiência histórica de desenvolvimento. In: História Geral da Civilização Brasileira. 2. ed. Tomo III, O Brasil Republicano, $4^{\circ}$ v. Economia e Cultura (1930-1964). São Paulo: DIFEL, 1986.

TRIGO, L. G. G. Sociedade pós-industrial e o profissional em turismo. São Paul: Papirus, 2003.

TURISMO, Cultura e Lazer - ETUR. A história da Hotelaria no Brasil e no Mundo. Disponível em: <"http://www.etur.com.br/" >. Acesso em: 11 de março de 2014.

VILLANUEVA, Simone. A Dinâmica da Localização da Hotelaria Curitibana no Período de 1966 a 2008. 2010. 204f. Tese (Doutorado em Geografia) - Setor Ciências da Terra, Universidade Federal do Paraná, Curitiba, 2010.

WALKER, J. R. Introdução à Hospitalidade. São Paulo: Manole, 2002. 